Theories \& Applications, the International Edition

Printed Version: (ISSN 2090-5262)

Online Version: (ISSN 2090-5270)

November 2013, Volume 3, No. 3 Pages (53 - 66)

\title{
The Athletic Future Anxiety and Its Relation with Gender and Specialization of High Level Aquatic Sports Players
}

\author{
Mostafa Samy Amira*, Muhammed Alazab Bahiery**
}

\section{Research Introduction and Problem}

$\mathrm{P}$ eople in general and youth in particular are usually concerned about the future, as concerning about the future is the main and basic component of thinking and it could be the biggest definer of behavior. Man is in a continuous quest towards the future, which is expressed by Abdel Salam Abdel Ghafar (the existence will) as the permanent power that pushes, directs and organizes human activity towards self achievement in order to reach the suitable level of integrated humanity. (202:8)

Samira Shind (2002) quoting from Tofler points out that future bears in its folds quick changes include all that surround man of economical, social, cultural and technical changes which are accompanied by changes of value, manners and behavioral structure...etc. which may shake man's stability and pushes him to psychological diseases. (113: 5)

It is so important to point out the anxiety conception briefly, before approaching future anxiety. As there were many ways that paid attention to interpreting anxiety involved the psychological explanation where Michel Eysenck (1997) saw it as the unilateral explanation especially that it neglects environmental and education factors despite its importance. $(5,6: 16)$

While Talaat Mansor (1995) saw that existential curve in anxiety interpretation is basically attached to knowledge significations of life, existence, relationships and future as all these meanings react with human's feeling of no

\footnotetext{
* Assistant Professor, Competitive and Aquatic Sports Department - Menoufia University, A.R.E.

** Assistant Professor, Competitive and Aquatic Sports Department-Alex. University, A.R.E.
}

significance in its reaction with events, relationships and situations and in its interpretation of them where existence as a whole is the anxiety question. (602: 6)

Abdel Aziz Abdel Megid and others (2007) refer that existential curve is associated with future direction - in comparison with analytical and behavioral - in addressing anxiety, man works while his mind is thinking about the future and looking forward to achieve his hopes in that future, he moves to fulfill his aims while his biggest worries are not to reach them. (2: 10)

Therefore, anxiety about the future studies started under different names; the most remarkable of which is the fear of future or the negative expectations about the future or the pessimism of the future or the unknown direction towards the future.

Zaleski (1994) had paved the way to define the conception of anxiety about the future through several studies about the conception of future anxiety, personal future, hope and anxiety prospective, self direction towards the future and its importance and the man's will, the danger of negative effect of knowledge bias in conceiving events, and surrounding circumstances, and that future anxiety is attached to awareness of environmental circumstances. (177: 23)

Zaleski (1996) also referred that the knowledge component is the basis behind the feeling of future anxiety. And that it depends on some conceptions of which are: the fear of failure according to Atkinson, and despair according to Beck, the fear of fate according to Telck (the existential school). It also depends on the conception of self effectiveness according to Pandura, and the conception of control according to Julian Rotter. It also depends on a semi-basic feature on Eysenck knowledge 
theory of anxiety. He also adopted threat evaluation definitions previously introduced by Eysenck in his theory where he mentioned that the individual passes since his childhood and adolescence through experiences that contribute to his knowledge and passion forming and the right experiences may lead him to thinking coherence and form the self effectiveness and positive self estimated personality that can understand the real image of events hence the response to future will be characterized by the healthy or ordinary anxiety, therefore, results in the creative reaction with life. (121: 5) (166: 24)

Abdel Aziz Abdel Megid and others (2007) add that anxiety level of the individual is one of the future anxiety sources, this is confirmed by Samira Shind (2002), Steven Reis (1997) and Michel Dugas (1998) (15) and others mentioned that the future anxiety is attached to anxiety as a character. (3: 10)

Thelma (1992) also referred that the character of anxiety is a behavioral acquired trend that makes the individual has the tendency to conceive a wide chain of non-danger subjective circumstances as a threat and to respond to these circumstances through state anxiety reactions that its degree suits the subjective danger degree. (121: 20)

The dictionary of Sport and Training Sciences has defined the anxiety feature as "a relatively remarkable personal tendency and trend to perceive certain environmental situations as considering it representing a threat or pressuring factor or the tendency to respond to these situations through increasing state anxiety". (59: 9) $(32,31,21)$

Daneil L (1997) adds that feature anxiety includes a severe tendency continues for a long time towards suffering from anxiety in pressuring situations which resembles personality variable, individuals who have high level of feature anxiety tend to conceive different situations requirements in high threatening method (136: 14), John Kremer (1994) agrees with that opinion; that feature anxiety is a trend of endurance that is more responding to exhaustion. (17:21)

Finally, Ronald Molin (1990) and Ashor Deiab (2001) saw that reasons of future anxiety can be represented in the existence of differences between individual ambition and its real potentials, and also vision failure towards the future, or lack of information or distortion of ideas. (504: 18) (437: 7)

Proceeding from that, Molin (1990) described who suffers from future anxiety that he feels pessimistic, have doubts, extra agitation and disorders, passivity and the feeling of insecure, lack of trust, lack of the ability to face the future and the fear of expected social, and political changes and the negative expectations of what the future might bear.

(505: 18)

Both Ibrahim Khalifa (1997) and Mahmoud Anan (1995) refer that athletic competitions are considered one of the most important pressure sources as being a situation of test and evaluation of player's abilities, that may include the feeling of fear, lack of confidence or lack of control on different factors attached to achieving winning in competitions and the financial and morale benefits due to it. (163: 1) (427: 12)

The two researchers think that what the successful athletics enjoy of feeling of selfconfidence, the ability to control emotions, optimism and the positive experiences of competition and training then, the feeling of competition and winning enjoyment and what results of that of financial and morale benefits and sometimes fame, and social and family position. In addition to the difference in the athletic ambition's level according to laws of profession and marketing internally and internationally. This clearly refers to athletic self-achievement and optimism in order to achieve successful and promising athletic future. On the contrary, the fear of injury and the control of negative competition experiences, lack of confidence, pessimism and the tendency to provocation in important competitive situations, also the fear of technical and administrative control and weakness or the athletic bureaucratic administration, and the shortage of advanced athletic equipments also the possibility of getting injured and what may result from that of factors and reasons can affect the athletic performance level, and hence the way he sees his athletic future. 
That urged the two researchers to study athletic future anxiety and its relation with gender variable (male/ female players) and with specialization (swimming - diving) of high level Aquatic sports players in a scientific attempt to find out the most important factors that the players see as reasons behind their anxiety about their athletic future to be the basis of scientific contribution in supporting the good training and psychological preparation of players.

\section{Research Aim}

1. To find out the level of athletic future anxiety of Aquatic sports players (swimming - diving).

2. To study the differences in athletic future anxiety and its effects among Aquatic sport players according to specialization (swimming diving).

3. To study the differences in athletic future anxiety and its effects among Aquatic sport players according to gender (male- female players).

\section{Research Questions}

1. What is the level of athletic future anxiety of Aquatic sport players (swimming - diving).

2. What are the differences of athletic future anxiety and its effects on Aquatic sport players according to specialization (swimming diving).

3. What are the differences of athletic future anxiety and its effects on Aquatic sport players according to gender (male- female players).

\section{Research Terms}

Athletic future anxiety:

Abdel Aziz Abdel Megid, Mostafa Amira and Nebal Badr (2007) define athletic future anxiety that it is "a state of feeling the threat about the athletic age future of the player". (5: 10)

\section{Previous Studies}

considering that the subject of this study is new in the sport environment locally and in the Arab world, as far as the two researchers know, there is a shortage in previous studies about "athletic future anxiety", but as the future anxiety prospects are diverse in general, this contributed in the existence of some studies which treated this subject from its different educative prospective of which we display what is more associated to this study.

Wenglert and Rosen (2000) (22) made a study displayed the relation between pessimism - as a synonym of future anxiety - and optimism and beliefs about the personal and universal future. The sample contained 183 males and females of different ages. The most important results showed the optimism of the majority of the sample personnel about the personal and universal future.

Ahmed Hassanin (2000) (2) also made a study targeted the relation between future anxiety and some variables of which are: the motivation to achievement, self- conception, and ambition level of 300 male and female students of high school in Menyia. The most important results showed the existence of negative attachment between future anxiety and basic study variables, and the lack of significant differences between males and females in future anxiety.

Heba Moayad Mohamed (2007) (13) also made a study aimed to measure the level of future anxiety of youth and its relation with gender, social status, profession, and age.

Abel Aziz Abedl Megid, Mostafa Amira and Nebal Badr (2007) (10) made a study aimed to build a measurement of players' future anxiety, research sample included a big number of athletics who compete on the high level among national teams players and also some first class players who represent 13 sport games. The most important results showed the validity of athletic future anxiety measurement for all athletics (male - female players). As through using it, we can recognize the reasons and factors that athletics think cause athletic future anxiety and that it enjoys high scientific interactions.

\section{Research Procedures}

\section{Research Method:}

The two researchers used the descriptive method as it suits the nature of this research.

\section{Research Society \& Sample:}


Research sample was selected deliberately of high levels swimming and diving players (malefemale players) represent the clubs (Heliopolis, Al-Zohor, Zamalek and Al-Gezira) registered in the Egyptian Union of Swimming season 2011/2012, the next table clarifies the description of research sample.

Table (1)

The research sample description of swimming male and female players

\begin{tabular}{|c|c|c|c|c|c|c|c|c|}
\hline \multirow{2}{*}{ Variables } & \multicolumn{3}{|c|}{ Swimming male-players N=45 } & \multicolumn{4}{c|}{ Swimming female-players N=30 } \\
\cline { 2 - 10 } & Mean & $\begin{array}{c}\text { Standard } \\
\text { deviation }\end{array}$ & Kurtosis & $\begin{array}{c}\text { Coefficient } \\
\text { of torsion }\end{array}$ & Mean & $\begin{array}{c}\text { Standard } \\
\text { deviation }\end{array}$ & $\begin{array}{c}\text { Kurtosis } \\
\text { Coefficient } \\
\text { of torsion }\end{array}$ \\
\hline Age & 14.56 & 1.57 & 0.51 & 1.04 & 13.87 & 0.86 & -1.62 & 0.27 \\
\hline Height & 166.56 & 6.94 & -0.83 & 0.31 & 154.6 & 1.90 & 2.16 & 1.26 \\
\hline Weight & 60.60 & 6.25 & -0.84 & 0.41 & 56.37 & 2.63 & -1.31 & -0.08 \\
\hline $\begin{array}{c}\text { Training } \\
\text { age }\end{array}$ & 5.44 & 1.47 & 1.51 & 1.24 & 4.9 & 0.88 & -1.37 & 0.20 \\
\hline $\begin{array}{c}\text { Competitive } \\
\text { age }\end{array}$ & 4.38 & 1.42 & 2.42 & 1.48 & 3.87 & 0.86 & -1.62 & 0.27 \\
\hline
\end{tabular}

Table (1) shows that Coefficient of torsion of matching of swimming sample personnel in growth variables of swimming male and female players is between \pm 3 , which indicates the

growth variables.

Table (2)

The research sample description of diving male and female players

\begin{tabular}{|c|c|c|c|c|c|c|c|c|}
\hline \multirow{2}{*}{ Variables } & \multicolumn{4}{|c|}{ Diving male-players N=37 } & \multicolumn{4}{c|}{ Diving female-players N=27 } \\
\cline { 2 - 10 } & Mean & $\begin{array}{c}\text { Standard } \\
\text { deviation }\end{array}$ & Kurtosis & $\begin{array}{c}\text { Coefficient } \\
\text { of torsion }\end{array}$ & Mean & $\begin{array}{c}\text { Standard } \\
\text { deviation }\end{array}$ & Kurtosis & $\begin{array}{c}\text { Coefficient } \\
\text { of torsion }\end{array}$ \\
\hline Age & 12.62 & 1.42 & -0.91 & 0.66 & 12.59 & 1.45 & -1.15 & 0.46 \\
\hline Height & $\begin{array}{c}151.3 \\
2\end{array}$ & 16.47 & -0.70 & -0.59 & $\begin{array}{c}142.1 \\
1\end{array}$ & 9.05 & -1.70 & -0.01 \\
\hline Weight & 49.24 & 13.88 & -0.25 & -0.37 & 41.96 & 7.78 & -1.74 & -0.01 \\
\hline Training age & 6.68 & 1.43 & -1.08 & 0.55 & 6.59 & 1.45 & -1.15 & 0.46 \\
\hline $\begin{array}{c}\text { Competitive } \\
\text { age }\end{array}$ & 4.62 & 1.42 & -0.91 & 0.66 & 4.59 & 1.45 & -1.15 & 0.46 \\
\hline
\end{tabular}

Table (2) shows that Coefficient of torsion of growth variables of diving male and female players is between \pm 3 , which indicates the matching of diving sample personnel in growth variables.

\section{Research Tools:}

First: the two researchers used the following in growth variables data gathering:

- A medical scale to measure weight in kilograms.

- A Restameter to measure height in centimeters.

Second: the two researchers used a measurement of (athletic future anxiety) designed by Abdel Aziz Abdel Megid and others (2007) and was designed for top level players. The measurement has high levels of honesty and stability - enclosed (1).

\section{The Pilot Study}

The two researchers performed a pilot study on a sample of (15) swimmers from outside the basic sample during the period 20/7/2012 to 2/8/2012 to find out:

- The level of understanding conditions and instructions of the used measurements procedure of the pilot sample.

- The scientific interactions count (honesty stability) of the used measurement. 
Table (3)

The description of Pilot research sample

\begin{tabular}{|c|c|c|c|c|}
\hline Variables & Mean & $\begin{array}{c}\text { Standard } \\
\text { deviation }\end{array}$ & Kurtosis & $\begin{array}{c}\text { Coefficient of } \\
\text { torsion }\end{array}$ \\
\hline Age & 16.33 & 1.29 & -0.51 & 0.66 \\
\hline Height & 174.53 & 3.85 & -1.31 & -0.32 \\
\hline Weight & 67.87 & 3.00 & 2.34 & 1.91 \\
\hline Training age & 7.00 & 1.36 & 0.50 & 0.98 \\
\hline $\begin{array}{c}\text { Competitive } \\
\text { age }\end{array}$ & 5.93 & 1.33 & 0.77 & 1.39 \\
\hline
\end{tabular}

Table (3) shows that variables Coefficient of The two researchers calculated test validity torsion studied in the research ranges between \pm 3 , which indicates the matching among pilot sample personnel.

The scientific interactions of athletic future anxiety measurement using test internal consistency.

Table (4) shows the Coefficient of torsion between measurement phrases and the dimensions which it belong to in every axis of the measurement three axis.

First: Validity:

Table (4)

The internal consistency coefficient between each phrase degree and thedimension degree to which it belongin the first axis

(the personal characteristics)

\begin{tabular}{|c|c|c|c|c|c|}
\hline \multicolumn{2}{|c|}{ Tendency to provocation } & \multicolumn{2}{|c|}{ Tendency to pessimism } & \multicolumn{2}{c|}{ Self-confidence } \\
\hline Phrase no. & $\begin{array}{c}\text { Correlation value } \\
\text { with dimension }\end{array}$ & Phrase no. & $\begin{array}{c}\text { Correlation value } \\
\text { with dimension }\end{array}$ & Phrase no. & $\begin{array}{c}\text { Correlation value } \\
\text { with dimension }\end{array}$ \\
\hline 1 & 0.775 & 2 & 0.756 & 3 & 0.781 \\
\hline 4 & 0.812 & 5 & 0.699 & 6 & 0.749 \\
\hline 7 & 0.538 & 8 & 0.638 & 9 & 0.829 \\
\hline
\end{tabular}

* The table value of $(R)$ at 0.05 at free degrees $13=0.512$

Table (4) shows the existence of statistically significant correlation coefficients between players degrees in all measurement phrases and the dimension to which they belong in the first axis (the personal characteristics) as correlation coefficient values varied between $(-0.638$ 0.829) which indicated that they have high stability interactions.

Table (5)

The internal consistency coefficient between each phrase degree and thedimension degree to which it belong in the second axis

(the athletic environment)

\begin{tabular}{|c|c|c|c|c|c|c|c|c|c|c|c|}
\hline \multicolumn{2}{|c|}{$\begin{array}{l}\text { The technical } \\
\text { \&administrative } \\
\text { board }\end{array}$} & \multicolumn{2}{|c|}{ Team Members } & \multicolumn{2}{|c|}{ Family } & \multicolumn{2}{|c|}{ Audience } & \multicolumn{2}{|c|}{ Mass media } & \multicolumn{2}{|c|}{ Athletic equipments } \\
\hline $\begin{array}{c}\text { Phrase } \\
\text { no. }\end{array}$ & $\begin{array}{l}\text { Correlation } \\
\text { value with } \\
\text { dimension }\end{array}$ & $\begin{array}{c}\text { Phrase } \\
\text { no. }\end{array}$ & $\begin{array}{l}\text { Correlation } \\
\text { value with } \\
\text { dimension }\end{array}$ & $\begin{array}{c}\text { Phrase } \\
\text { no. }\end{array}$ & $\begin{array}{l}\text { Correlation } \\
\text { value with } \\
\text { dimension }\end{array}$ & $\begin{array}{c}\text { Phrase } \\
\text { no. }\end{array}$ & $\begin{array}{l}\text { Correlation } \\
\text { value with } \\
\text { dimension }\end{array}$ & $\begin{array}{c}\text { Phrase } \\
\text { no. }\end{array}$ & $\begin{array}{l}\text { Correlation } \\
\text { value with } \\
\text { dimension }\end{array}$ & $\begin{array}{c}\text { Phrase } \\
\text { no. }\end{array}$ & $\begin{array}{l}\text { Correlation } \\
\text { value with } \\
\text { dimension }\end{array}$ \\
\hline 10 & 0.529 & 11 & 0.671 & 12 & 0.743 & 13 & 0.794 & 14 & 0.626 & 20 & 0.641 \\
\hline 15 & 0.520 & 16 & 0.659 & 17 & 0.629 & 18 & 0.781 & 19 & 0.580 & 26 & 0.699 \\
\hline 21 & 0.623 & 22 & 0.628 & 23 & 0.843 & 24 & 0.589 & 25 & 0.672 & 29 & 0.615 \\
\hline 27 & 0.688 & & & & & & & 28 & 0.643 & & \\
\hline
\end{tabular}

* The table value of $(R)$ at 0.05 at free degrees $13=0.512$

Table (5) shows the existence of statistically significant correlation coefficients between players degrees in all measurement phrases and the dimension to which they belong in the second axis (the athletic environment) as correlation coefficient values varied between ( $0.794-0.520)$ which indicated that they have high stability interactions. 
Table (6)

The internal consistency coefficient between each phrase degree and thedimension degree to which it belong in the third axis

(the competition outcome)

\begin{tabular}{|c|c|c|c|c|c|}
\hline \multicolumn{2}{|c|}{ Injury } & \multicolumn{2}{c|}{ Profession revenue } & \multicolumn{2}{c|}{ Negative experiences } \\
\hline Phrase no. & $\begin{array}{c}\text { Correlation } \\
\text { value with } \\
\text { dimension }\end{array}$ & Phrase no. & $\begin{array}{c}\text { Correlation } \\
\text { value with } \\
\text { dimension }\end{array}$ & Phrase no. & $\begin{array}{c}\text { Correlation value } \\
\text { with dimension }\end{array}$ \\
\hline 30 & 0.684 & 31 & 0.696 & 32 & 0.599 \\
\hline 33 & 0.520 & 34 & 0.544 & 35 & 0.842 \\
\hline 36 & 0.664 & 38 & 0.689 & 37 & 0.684 \\
\hline 40 & 0.713 & 41 & 0.743 & 39 & 0.626 \\
\hline & & & & 42 & 0.587 \\
\hline
\end{tabular}

* The table value of $(R)$ at 0.05 at free degrees $13=0.512$

Table (6) shows the existence of statistically axis (the competition outcome) as correlation significant correlation coefficients between coefficient values varied between $(0.842-$ players degrees in all measurement phrases and 0.520) which indicated that they have high the dimension to which they belong in the third stability interactions.

Table (7)

The internal consistency correlation between each axis degree and the total degree of athletic future anxiety measurement

$N=15$

\begin{tabular}{|c|c|}
\hline Future anxiety axes & Correlation coefficient \\
\hline The 1st axis the personal characteristics & 0.685 \\
\hline The 2nd axis the athletic environment & 0.555 \\
\hline The 3rd axis the competition outcome & 0.521 \\
\hline
\end{tabular}

* The table value of $(R)$ at 0.05 at free degrees $13=0.512$

Table (7) shows the existence of statistically significant correlation coefficients between players degrees in all measurement phrases and the dimension to which they belong in the first axis (the personal characteristics) as correlation coefficient values varied between ( -0.332
0.685) which indicated that they have high stability interactions.

\section{Second: Reliability}

The two researchers used test re-application method with time separation of 10 days from the first application.

Table (8)

The differences between the 1 st \& the 2 nd applications in future anxiety measurement axes

$$
N 1=N 2=15
$$

\begin{tabular}{|c|c|c|c|c|c|c|c|}
\hline & \multirow{2}{*}{$\begin{array}{c}(\mathrm{T}) \\
\text { Valculated } \\
\text { value }\end{array}$} & $\begin{array}{c}\text { Difference } \\
\text { between the } 2 \\
\text { averages }\end{array}$ & $\begin{array}{c}\text { Standard } \\
\text { deviation }\end{array}$ & mean & $\begin{array}{c}\text { Standard } \\
\text { deviation }\end{array}$ & mean & Significance \\
\hline $\begin{array}{c}\text { Personal } \\
\text { characteristics }\end{array}$ & 12.93 & 1.79 & 12.60 & 2.03 & 0.33 & 0.477 & $\begin{array}{c}\text { Not } \\
\text { significant }\end{array}$ \\
\hline $\begin{array}{c}\text { Athletic } \\
\text { environment }\end{array}$ & 35 & 2.75 & 35.06 & 3.08 & -6.66 & -0.063 & $\begin{array}{c}\text { Not } \\
\text { significant }\end{array}$ \\
\hline $\begin{array}{c}\text { Competition } \\
\text { outcome }\end{array}$ & 24.13 & 2.41 & 24.60 & 1.50 & $0.46-$ & -0.635 & $\begin{array}{c}\text { Not } \\
\text { significant }\end{array}$ \\
\hline $\begin{array}{c}\text { The total degree of } \\
\text { future anxiety }\end{array}$ & 72.06 & 3.55 & 72.26 & 4.02 & -0.20 & -0.144 & $\begin{array}{c}\text { Not } \\
\text { significant }\end{array}$ \\
\hline
\end{tabular}

* The table value of $(R)$ at 0.05 at free degrees $13=0.512$

Table (8) shows the lack of statistically significant differences in the first and the second applications of athletic future anxiety measurement axes, and also its total degree at 
level (0.05). This indicates that the measurement has a high degree of stability.

\section{Basic study:}

After calculating the scientific interactions of the used measurement, the two researchers performed the basic application of athletic future anxiety on research basic sample of swimming and diving male and female players during the period from $7 / 8 / 2012$ to $16 / 8 / 2012$.

\section{Correcting forms and preparing data for} statistical treatment:

The two researchers corrected athletic future anxiety measurement according to its correction key - enclosed (1) then preparing data for statistical treatments.

\section{Statistical treatment:}

The following statistical treatments were used:

- Arithmetic Mean

- Kurtosis

- Standard Deviation

- Coefficient of torsion

- Simple Correlation Coefficient

- "T" Test

The two researchers approved the statistical significant level at 0.05 to confirm results morale.

\section{Displaying and discussing results:}

Table (9)

The differences of athletic future anxiety level and its dimensions in swimming sport according to gender (male female players)

\begin{tabular}{|c|c|c|c|c|c|c|c|}
\hline \multirow[b]{2}{*}{ Variables } & \multicolumn{2}{|c|}{$\begin{array}{l}\text { swimming male } \\
\text { players } \mathrm{N}=45\end{array}$} & \multicolumn{2}{|c|}{$\begin{array}{l}\text { swimming female } \\
\text { players } \mathrm{N}=30\end{array}$} & \multirow{2}{*}{$\begin{array}{c}\text { Difference } \\
\text { between } \\
\text { the } 2 \\
\text { means }\end{array}$} & \multirow{2}{*}{$\begin{array}{c}\text { "T" } \\
\text { calculated } \\
\text { value }\end{array}$} & \multirow[b]{2}{*}{ Significance } \\
\hline & Mean & $\begin{array}{l}\text { Standard } \\
\text { deviation }\end{array}$ & Mean & $\begin{array}{l}\text { Standard } \\
\text { deviation }\end{array}$ & & & \\
\hline Tendency to provocation & 6.066 & 1.543 & 7.6 & 0.968 & -1.533 & -0.721 & significant \\
\hline Inclination to pessimism & 3.622 & 0.490 & 6.633 & 0.718 & -3.011 & -11.635 & Significant \\
\hline Self-confidence & 3.155 & 0.366 & 3.233 & 0.568 & -0.777 & -0.117 & $\begin{array}{c}\text { Not } \\
\text { significant }\end{array}$ \\
\hline Personal characteristics & 12.844 & 1.845 & 17.466 & 1.407 & -4.622 & -32.11 & Significant \\
\hline $\begin{array}{c}\text { Technical \& administrative } \\
\text { board }\end{array}$ & 9.288 & 1.914 & 9.333 & 0.994 & -0.444 & 3.424 & $\begin{array}{c}\text { Not } \\
\text { Significant }\end{array}$ \\
\hline Team members & 3.333 & 0.476 & 7.6 & 0.674 & -4.266 & -10.747 & Significant \\
\hline Family & 3.666 & 1.00 & 3.033 & 0.182 & 0.633 & 11.582 & significant \\
\hline Audience & 3.533 & 0.625 & 5.733 & 0.968 & -2.2 & -2.675 & significant \\
\hline Mass media & 8.977 & 1.588 & 5.5 & 0.718 & 3.477 & -5.111 & Significant \\
\hline Athletic equipments & 6.688 & 1.395 & 7.466 & 0.568 & -0.777 & -3.787 & Significant \\
\hline Athletic environment & 35.489 & 3.042 & 38.666 & 1.407 & -3.177 & 10.737 & Significant \\
\hline Injury & 8.333 & 1.581 & 9.566 & 0.994 & -1.233 & 2.386 & Significant \\
\hline Profession revenue & 9.00 & 0.00 & 6.7 & 0.674 & 2.3 & 3.892 & Significant \\
\hline Negative experiences & 6.866 & 1.254 & 6.233 & 0.182 & 0.633 & -7.62 & Significant \\
\hline Competition outcome & 24.2 & 1.925 & 22.5 & 0.968 & 1.7 & -21.596 & Significant \\
\hline Future anxiety & 72.533 & 3.727 & 78.633 & 0.718 & -6.1 & -0.721 & Significant \\
\hline
\end{tabular}

T test spreadsheet values at morale level 0.05 and free degree $73=1.98$

Related to the differences in the first axis (personal characteristics) according to athletic future anxiety.

Table (9) shows that there are statistically shown differences in the first axis dimension in swimming sport according to gender variable between (male - female swimmers) in favor of female swimmers in the following dimensions: tendency to provocation, tendency to pessimism, and the total of first axis.

This result means that the female swimmers have anxiety about their athletic future especially concerning the tendency to provocation and tendency to pessimism more than male swimmers which indicates that these dimensions represent one of the personal sources of athletic future anxiety.

Concerning the second axis differences (the athletic environment) according to athletic future anxiety.

Table (9) shows that there are statistically significant differences in the second axis dimensions in swimming sport according to 
gender variable between (male - female swimmers) in favor of female swimmers in the dimensions: team members, the audience, athletic equipments and second axis total.

This table indicated also that there are statistically significant differences between male and female swimmers in favor of male swimmers in the dimensions: the family, and mass media. The two researchers attribute that to the competitive contribution of male swimmers that vary on more than one level locally or internationally, therefore, they are affected by what mass media publish about them in addition to family too and its important role in enduring many loads and responsibilities along player's training age years especially the many times of training, the different places sometimes, and the schedule which is often more than once a day and for this family satisfaction and facing it could be very difficult on the player, hence it is considered one of athletic future anxiety sources.

Concerning differences of the third axis (competition outcome) according to athletic future anxiety measurement.
Table (9) shows that there are statistically significant differences in the third axis dimensions in swimming sport according to gender variable between (male - female swimmers) in favor of female swimmers in the dimension: the injury, while there are also statistically significant differences in favor of male swimmers in the profession revenue dimension, and the negative experiences, and the third axis total.

The differences also came in the total measurement of athletic future anxiety in swimming sport according to gender variable (male - female swimmers) statistically significant differences in favor of female swimmers; this means the increase of their athletic future anxiety level compared to male swimmers. These results agree with the study of Boshra Ahmed (2000), Heba Moayad (2005) and Fadila Arafat (2007) which showed the morale significant differences at the future anxiety level in favor of females compared to males.

Table (10)

The differences in the athletic future anxiety level and its dimensions in diving sport according to gender (male female players)

\begin{tabular}{|c|c|c|c|c|c|c|c|}
\hline \multirow[b]{2}{*}{ Variables } & \multicolumn{2}{|c|}{$\begin{array}{c}\text { diving male players } \\
\mathrm{N}=37\end{array}$} & \multicolumn{2}{|c|}{$\begin{array}{l}\text { diving female } \\
\text { players } N=27\end{array}$} & \multirow{2}{*}{$\begin{array}{c}\text { Difference } \\
\text { between } \\
\text { the } 2 \\
\text { means }\end{array}$} & \multirow{2}{*}{$\begin{array}{c}\text { "T" } \\
\text { calculated } \\
\text { value }\end{array}$} & \multirow[b]{2}{*}{ Significance } \\
\hline & Mean & $\begin{array}{l}\text { Standard } \\
\text { deviation }\end{array}$ & Mean & $\begin{array}{l}\text { Standard } \\
\text { deviation }\end{array}$ & & & \\
\hline Tendency to provocation & 7.16 & 1.67 & 5.03 & 0.34 & 2.13 & 6.48 & significant \\
\hline Inclination to pessimism & 4.51 & 1.60 & 7.55 & 0.69 & -3.04 & -9.19 & Significant \\
\hline Self-confidence & 3.24 & 0.43 & 3.37 & 0.49 & -0.12 & -1.09 & $\begin{array}{c}\text { Not } \\
\text { significant }\end{array}$ \\
\hline Personal characteristics & 14.91 & 1.03 & 15.96 & 0.89 & -1.04 & -4.20 & Significant \\
\hline $\begin{array}{c}\text { Technical \& administrative } \\
\text { board }\end{array}$ & 8.91 & 1.34 & 7.37 & 1.07 & 1.54 & 4.94 & Significant \\
\hline Team members & 3.21 & 0.41 & 3.55 & 0.50 & -0.33 & -2.93 & Significant \\
\hline Family & 3.03 & 0.16 & 3.00 & 0.00 & 0.027 & 0.85 & $\begin{array}{c}\text { Not } \\
\text { significant }\end{array}$ \\
\hline Audience & 4.54 & 1.28 & 5.74 & 0.45 & -1.20 & -4.65 & significant \\
\hline Mass media & 6.08 & 2.64 & 9.81 & 1.14 & -3.73 & -6.85 & Significant \\
\hline Athletic equipments & 7.73 & 0.93 & 6.33 & 0.48 & 1.39 & 7.11 & Significant \\
\hline Athletic environment & 33.51 & 3.23 & 35.81 & 1.46 & -2.30 & -3.43 & Significant \\
\hline Injury & 7.67 & 2.43 & 4.00 & 0.00 & 3.67 & 7.81 & Significant \\
\hline Profession revenue & 4.78 & 0.71 & 5.77 & 1.15 & -0.99 & -4.25 & Significant \\
\hline Negative experiences & 10.59 & 1.36 & 10.22 & 1.34 & 0.37 & 1.08 & $\begin{array}{c}\text { Not } \\
\text { Significant }\end{array}$ \\
\hline Competition outcome & 23.05 & 3.13 & 20.00 & 1.94 & 3.05 & 4.46 & Significant \\
\hline Future anxiety & 71.48 & 3.21 & 71.77 & 2.94 & -0.29 & -0.37 & $\begin{array}{c}\text { Not } \\
\text { Significant }\end{array}$ \\
\hline
\end{tabular}

T test spreadsheet values at morale level 0.05 and free degree $63=1.98$ 
Concerning the first axis differences (personal characteristics) according to athletic future anxiety.

Table (10) shows that there are statistically significant differences in the first axis dimension in diving sport according to gender variable between (male - female players) in favor of male players in the tendency to provocation dimension, in favor of female players in the tendency to pessimism dimension and the first axis total.

The two researchers attribute these differences to the resulted outcomes in diving sport as an individual sport in which the player bears the sole responsibility of winning and defeat like all individual sports contrary to team sports, which indicates that the personal characteristics of which the tendency to Provocation and inclination to pessimism which are considered of the important sources of threat to diving male and female players.

Concerning the second axis differences (the athletic environment) according to athletic future anxiety.

Table (10) shows that there are statistically significant differences in the second axis dimension in diving sport according to gender variable between (male - female players) in favor of male players in the dimensions: the technical and administrative board, the athletic equipments. The two researchers justify these differences that the diving male players worry about their athletic level which is affected by the existence of good technical and administrative board or not, and then the importance of affording athletic equipments which effectively contribute in developing player's level and in turn his athletic future.

Table (10) also indicated that there are statistically significant differences between diving male and female players in favor of diving female players in the dimensions: team members, the audience, mass media and the second axis total. The two researchers justify that the technical level of female players and their concentration when performing may be affected by these effects more than the male players in diving sport.

Concerning the third axis differences (competition outcome) according to athletic future anxiety.

Table (10) shows that there are statistically significant differences in the third axis dimensions in diving sport according to gender variable between (male - female players) in favor of male players in injury dimension and the third axis total, while the results indicated also that there are significant differences in favor of female players in the profession revenue dimension which means that diving male and female players have a high level of athletic future anxiety despite the different importance of the reasons behind this anxiety between male and female players.

The differences also in total athletic future anxiety measurement in diving sport according to gender variable between (male - female players) were not statistically significant differences between male players and female players. These results agree with the indication of Rashid Al Hashimy (2001) study. 
Table (11)

The differences of athletic future anxiety level and its dimensions between aquatic sports male players according to specialization (swimming - diving)

\begin{tabular}{|c|c|c|c|c|c|c|c|}
\hline \multirow{2}{*}{ Variables } & \multicolumn{2}{|c|}{$\begin{array}{c}\text { Swimming male } \\
\text { players N=45 }\end{array}$} & \multicolumn{2}{c|}{$\begin{array}{c}\text { diving male players } \\
\text { N=37 }\end{array}$} & $\begin{array}{c}\text { Difference } \\
\text { between } \\
\text { the 2 } \\
\text { means }\end{array}$ & $\begin{array}{c}\text { "T" } \\
\text { calculated } \\
\text { value }\end{array}$ & Significance \\
\cline { 2 - 7 } & Mean & $\begin{array}{c}\text { Standard } \\
\text { deviation }\end{array}$ & Mean & $\begin{array}{c}\text { Standard } \\
\text { deviation }\end{array}$ & \\
\hline Tendency to provocation & 6.06 & 1.543 & 7.16 & 1.675 & -1.095 & -3.078 & significant \\
\hline Inclination to pessimism & 3.62 & 0.490 & 4.51 & 1.609 & -0.891 & -3.526 & Significant \\
\hline Self-confidence & 3.15 & 0.366 & 3.24 & 0.435 & -0.087 & 0.991 & $\begin{array}{c}\text { Not } \\
\text { significant }\end{array}$ \\
\hline Personal characteristics & 12.84 & 1.845 & 14.91 & 1.037 & -2.074 & -6.087 & Significant \\
\hline $\begin{array}{c}\text { Technical \& administrative } \\
\text { board }\end{array}$ & 9.28 & 1.914 & 8.918 & 1.341 & 0.37 & 0.992 & $\begin{array}{c}\text { Not } \\
\text { Significant }\end{array}$ \\
\hline Team members & 3.33 & 0.476 & 3.216 & 0.417 & 0.117 & 1.17 & $\begin{array}{c}\text { Not } \\
\text { Significant }\end{array}$ \\
\hline Family & 3.66 & 1.00 & 3.027 & 0.164 & 0.639 & 3.844 & significant \\
\hline Audience & 3.53 & 0.625 & 4.540 & 1.282 & -1.007 & -4.645 & significant \\
\hline Mass media & 8.97 & 1.588 & 6.081 & 2.649 & 2.896 & 6.121 & Significant \\
\hline Athletic equipments & 6.68 & 1.395 & 7.729 & 0.932 & -1.040 & -3.879 & Significant \\
\hline Athletic environment & 35.48 & 3.042 & 33.513 & 3.237 & 1.975 & 2.843 & Significant \\
\hline Injury & 8.33 & 1.581 & 7.675 & 2.438 & 0.657 & 1.472 & $\begin{array}{c}\text { Not } \\
\text { Significant }\end{array}$ \\
\hline Profession revenue & 9.00 & 0.00 & 4.783 & 0.712 & 4.216 & 39.755 & Significant \\
\hline Negative experiences & 6.86 & 1.254 & 10.594 & 1.363 & -3.727 & -12.878 & Significant \\
\hline Competition outcome & 24.2 & 1.925 & 23.054 & 3.135 & 1.145 & 2.031 & Significant \\
\hline Future anxiety & 72.53 & 3.727 & 71.486 & 3.211 & 1.046 & 1.346 & $\begin{array}{c}\text { Not } \\
\text { Significant }\end{array}$ \\
\hline
\end{tabular}

T test spreadsheet values at morale level 0.05 and free degree $80=1.98$

Concerning the first axis differences (personal characteristics) according to athletic future anxiety measurement.

Table (11) shows that there are statistically significant differences between aquatic sports male players according to specialization (swimming - diving) in favor of diving male players in the dimensions: the tendency to provocation, the inclination to pessimism, and the first axis total. The two researchers justify that the time of performing the dive is less than the performance time of swimming players. So, the personal characteristics have much more effect, hence they are too of the most important sources of athletic future anxiety of diving male players in particular and in water sport in general.

Concerning the second axis differences (the athletic environment) according to athletic future anxiety.

Table (11) shows that there are statistically significant differences between aquatic sports male players according to specialization (swimming - diving) in favor of swimming male players in the 2 dimensions: the family, and mass media. While the significant differences were also in favor of diving male players in the 2 dimensions: the audience and the athletic equipments. The two researchers justify these results that the swimming male players may be because they are more popular in mass media than the diving players may be as the history of Egyptian swimming players on the Arabic, African and Mediterranean level more than diving male players. The two researchers justify the result of diving male players that the importance of affording the training athletic equipment to develop their technical level. As for the audience, they perform great moves the audience react to them and they feel them more than swimming male players.

Concerning the third axis differences (competition outcome) according to athletic future anxiety measurement.

Table (11) shows that there are statistically significant differences between aquatic sports male players according to specialization (swimming - diving) in favor of swimming male players in the profession revenue 
dimension and the axis total. While the statistically significant differences came in favor of diving male players in the negative experiences dimension. The two researchers justify these differences that the swimming male players get affected more by the profession revenue or the awards (financial or morale) because they participate in many competitions during the competitive season compared to diving male players, while the negative experiences of diving male players are more effective because of the small number of competitions during the season. For that, there is no other chance to compensate the performance failure which represents a psychological load on diving male players more than swimming male players in the third axis.

Table (12)

The differences in athletic future anxiety level and its dimensions between aquatic sports female players according to specialization

(swimming - diving)

\begin{tabular}{|c|c|c|c|c|c|c|c|}
\hline \multirow{2}{*}{ Variables } & \multicolumn{2}{|c|}{$\begin{array}{l}\text { Swimming female } \\
\text { players } N=27\end{array}$} & \multicolumn{2}{|c|}{$\begin{array}{l}\text { Swimming male } \\
\text { players } \mathrm{N}=30\end{array}$} & \multirow{2}{*}{$\begin{array}{c}\text { Difference } \\
\text { between } \\
\text { the } 2 \\
\text { means }\end{array}$} & \multirow{2}{*}{$\begin{array}{c}\text { "T" } \\
\text { calculated } \\
\text { value }\end{array}$} & \multirow[b]{2}{*}{ Significance } \\
\hline & Mean & $\begin{array}{l}\text { Standard } \\
\text { deviation }\end{array}$ & Mean & $\begin{array}{l}\text { Standard } \\
\text { deviation }\end{array}$ & & & \\
\hline Tendency to provocation & 7.6 & 0.968 & 5.037 & 0.337 & 2.563 & 13.046 & significant \\
\hline Inclination to pessimism & 6.633 & 0.718 & 7.555 & 0.698 & -0.922 & -4.905 & Significant \\
\hline Self-confidence & 3.233 & 0.568 & 3.370 & 0.492 & -0.137 & -968 & $\begin{array}{c}\text { Not } \\
\text { significant }\end{array}$ \\
\hline Personal characteristics & 17.466 & 1.407 & 15.963 & 0.897 & 1.503 & 4.747 & Significant \\
\hline $\begin{array}{c}\text { Technical \& administrative } \\
\text { board }\end{array}$ & 9.333 & 0.994 & 7.370 & 1.079 & 1.963 & 7.147 & Significant \\
\hline Team members & 7.6 & 0.674 & 3.555 & 0.506 & 4.044 & 25.368 & Significant \\
\hline Family & 3.033 & 0.182 & 3.00 & 0.00 & 0.033 & 0.948 & $\begin{array}{c}\text { Not } \\
\text { significant }\end{array}$ \\
\hline Audience & 5.733 & 1.142 & 5.740 & 0.446 & -0.007 & -0.032 & $\begin{array}{c}\text { Not } \\
\text { significant }\end{array}$ \\
\hline Mass media & 5.5 & 0.508 & 9.814 & 1.144 & -4.314 & -18.708 & Significant \\
\hline Athletic equipments & 7.466 & 0.937 & 6.333 & 0.480 & 1.133 & 5.648 & Significant \\
\hline Athletic environment & 38.666 & 1.863 & 35.814 & 1.468 & 2.851 & 6.368 & Significant \\
\hline Injury & 9.566 & 1.006 & 4.00 & 0.00 & 5.566 & 28.718 & Significant \\
\hline Profession revenue & 6.7 & 1.442 & 5.777 & 1.1547 & 0.922 & 2.646 & Significant \\
\hline Negative experiences & 6.233 & 0.897 & 10.222 & 1.339 & -3.988 & -13.326 & Significant \\
\hline Competition outcome & 22.5 & 1.737 & 20 & 1.941 & 2.5 & 5.132 & Significant \\
\hline Future anxiety & 78.633 & 2.822 & 71.777 & 2.939 & 6.855 & 8.979 & Significant \\
\hline
\end{tabular}

T test spreadsheet values at morale level 0.05 and free degree 55=2.00

Concerning the first axis differences (personal characteristics) according to athletic future anxiety measurement.

Table (12) shows that there are statistically significant differences between aquatic sports female players according to specialization (swimming - diving) in favor of swimming female players in the tendency to provocation dimension and the first axis total. While the differences came in favor of diving female players in the inclination to pessimism dimension. The two researchers justify these differences that swimming female players have more tendency to provocation considering the nature of swimming competitions in which times and numbers of each female player are already known. As for the inclination to pessimism in diving female players considering the competitive nature and what it requires of strong capability of concentration focus.

Concerning the second axis differences (the athletic environment) according to athletic future anxiety.

Table (12) shows that there are statistically significant differences between aquatic sports female players according to specialization (swimming - diving) in favor of swimming female players in the dimensions: technical \& administrative board - team members - athletic equipments - and the second axis total. 
The two researchers justify these differences to the swimming sport nature as a digital game depends on fractions of seconds, so the technical \& administrative board and athletic equipments are very important to maintain and promote the digital level of female players. Also considering swimming competitions nature and its sequences so the team members and their qualification are very important and influencing on female players level of anxiety about their athletic future.

This table also refers to the existence of statistically significant differences between swimming and diving female players in favor of diving in the mass media dimension.

Concerning the third axis differences (competition outcome) according to athletic future anxiety measurement.

Table (12) shows that there are statistically shown differences between aquatic sports female players according to specialization (swimming - diving) in favor of swimming female players in the dimensions: injury, profession revenue, and the third axis total, the two researchers attribute this to the many often times of competitive participation (local international) of swimming female players during the athletic season more than the diving female players.

The results also indicated that there are differences in favor of diving female players in the negative experiences dimension.

The two researchers attribute these results to the few times of competitive participation of diving female players during the athletic season, hence the negative experiences affect psychologically and are considered one of the most important sources of diving female players' athletic future anxiety.

Finally, table (11) Shows that there are statistically significant differences between swimming and diving female players in favor of diving female players in the total measurement of athletic future anxiety.

\section{Conclusions}

Limited to the used sample and research results, the two researchers concluded the following:
1. There are statistically significant differences in the athletic future anxiety level and its dimensions in swimming sport according to gender (male -female simmers) in favor of female swimmers.

2. There are no statistically significant differences in the athletic future anxiety level and its dimensions in diving sport according to gender (male - female players).

3. There are statistically significant differences in athletic future anxiety level and its dimensions between aquatic sports female players according to specialization (swimming diving) in favor of diving female players.

4. There are no statistically significant differences in the athletic future anxiety level and its dimensions between male players in aquatic sports according to specialization (swimming - diving).

5. Comparing the real average value and the theoretical average of athletic future anxiety level studied in the research, it is clear that the athletic future anxiety level of sample personnel in general is above average level.

\section{Recommendations}

1. Enlightening the athletic youth (male -female players) of their athletic future through recognizing their real capabilities and showing them the necessity of using these specific measurements to find out the most important sources and reasons of athletic future anxiety whether they were reasons related to personal characteristics or athletic environment or athletic competition outcome in order to realize, face and overcome these reasons and in order not to let these athletic youth become victims of their unrealistic ambitions and consequently waste a lot of opportunities due to generalizing some failure experiences.

2. To work through educational institutions, family, clubs and athletic establishments in order to pay attention to athletic psychological needs and to decrease their fears about the future through helping them in planning the future taking in consideration that man is the future maker.

3. To perform other researches about athletic future anxiety with other psychological 
variables such as (ambition level, achievement motivation and mental skills).

4. To make other researches about athletic future anxiety with other demographic variables such as (political aspects) and its effect on athletic future.

5. To make more researches on other athletic samples such as (handicapped).

\section{References}

\section{Arabic References}

1. Ibrahim Abd Rabo Khalifa (1997): Scientific Publications in the athletic field, the Supreme Council of Youth and Sport, Training Office for Preparing Leaders.

2. Ahmed Hassanin Ahmed (2000): "Future and Test Anxiety and its relation with some variables in 2nd secondary grade students sample" Master thesis, unpublished, Faculty of Arts, Menyia University.

3. Boshra Ahmed Jassem El Akayshy (2000): "Future Anxiety and its relation with some variables in university students", Master thesis, unpublished, Al Mostanseryia University.

4. Rashid Naser Khalifa Al Hashimy (2001): "Future Anxiety and its relation with the antisociety attitude in university students", (Master thesis, unpublished), Faculty of Education, Baghdad University.

5. Samria Mohamed Shind (2001): "Future Anxiety study and death anxiety in university student from the prospective of sex and specialization variables" Faculty of Education Magazine, Ain Shams University, Vol. 8, 3rd issue, p. 113- 181.

6. Talaat Mansour (1995): "the study of socialpsychological effects of the Iraqi invasion of Kuwait", world of knowledge chain, issue 195, Kuwait.

7. Ashour Mohamed Deyab (2001): "the effectiveness of religious-psychological guidance in easing future anxiety in university students' sample", researches in education and psychology magazine, Faculty of Education, Menyia University, vol. 15, issue 1, p. 436 466.
8. Abdel Aziz Abdel Ghafar (1981): "Introduction in Psychological Health", Dar Alnahda Alarabyia, Cairo.

9. Abdel Aziz Abdel Megid (2007): "the Psychology of facing pressures in the athletic field, edition 2, Elketab centre for publishing, Cairn.

10. Abdel Aziz Abdel Megid, Mostafa Amira and Nebal Badr (2007): "forming an athletic future anxiety measurement", Faculty of Education Magazine, vol. 18, issue 74, Benha University.

11. Fadila Arafat Alsabawey (2007): "future anxiety in Faculty of Education students and its relation with sex and study specialization", Faculty of Education Magazine, Al Maousel University.

12. Mahmoud Abdel Fatah Anan (1995): psychology of physical education and sport, the theory, the application and the experiment, Dar Alfekr Alaraby, Cairo.

13. Heba Moayad Mohamed (2007): "future anxiety in youth and its relation with some variables", magazine of educational and psychological researches, issue 26, p. 321-376.

\section{Foreign References}

1. Daniel, L. Wann (1997): Sport psychology, prentice-Hall, U.S.A.

2. Dugas, Michel J; Freeston, Mark H; ladauceur, Robert; Rheaume, Josee; Provencher, Martin \& Boisvert, Jean-Marie. (1998): "Worry Themes in primary GAM, secondary GAD, and other anxiety disorders". Journal of Anxiety Disorders. Vol. 12(3); PP: 253-261.

3. Eysenck, Michael W. (1997): "Anxiety and cognition A unified theory". Psychology press, Taylor \& Francis group.

4. John Kremer \& Deirdrescully (1994): Psychology in sport, Taylor \& Francis, London.

5. Molin, Ronald (1990): "Future anxiety: Clinical issues of children in the latter phases of foster care". Child \& Adolescent social work Journal. Vol 7(6); PP: 501-512.

6. Rice, Steven (1997): "Trait anxiety: It's not what you it is" Journal of Anxiety Disorders. Vol. 11(2); PP: 201-214. 
7. Thelma, S. Horn (1992): Advances in sport psychology, Human Kinetics Publisher,. U.S.A.

8. Tony Morris \& Jeff Summers (1995): Sport psychology, theory, Applications and issues, Jacaranda wiley, Australia.

9. Wenglert, Leif \& Rosen, Anne-Sofie (2000): "Measuring optimism-pessimism from belief about future events". Personality and individual differences. Vol. 28, PP: 717-728.
10. Zaleski, Zbigniew (1994): "Personal future in hope and anxiety perspective". In zbigniew, Zaleski (Ed) Psychology of future orientation. Scientific society of the catholic uni, of Lublin, No. 32. (PP: 173-194).

11. Zaleski, Zbigniew (1996): "Future Anxiety: Concept, Measurement, and Preliminary Research". Personality and individual Differences. Vol. 21, 2, PP: 165-174. 